\title{
FORMATION OF THE SCIENTIFIC ELITE IN CONTRACTING CONDITIONS OF HIGHER EDU- CATION
}

MACHYNSKA Nataliya,

Doctor Science in Pedagogy, Chief of Preschool and Primary Education Department, Ivan Franko National University of L'viv

Abstract. Introduction. Formation of the scientific elite in the establishment of higher education is a problem of scientific research in various directions: philosophical, sociological, psychological, pedagogical; in various aspects of scientific research by researchers: the will to power, the formation of personal identity, the acquisition of independence, self-actualization, etc.

Purpose. To analyze the peculiarities of formation of the scientific elite at the stage of professional formation in the conditions of higher education establishment; determine the main factors that ensure the development of elitist thinking.

Methods. To realize this purpose, such methods are used: empirical - during practical research; theoretical for the study and analysis of scientific and methodical literature, generalization of information for the definition of theoretical and practical foundations of the study; method of generalization - to distinguish factors that influence the development of elitist thinking

Results. In the course of the research, we identified the factors that ensure the development of elitist thinking in the students of the magistracy; interdependenc of the concepts of "elitism" and "acmeology" are shown. The expediency of using the conceptual apparatus of acmeology in the context of the research of the phenomenon of the scientific elite: "professional competence" and "acmeological competence" is shown.
Originality. The scientific novelty of the research is to choose the research problem; systematic analysis of theoretical studies of the formation of the scientific elite in the establishment of higher education; the substantiation of the factors that ensure the development of elite thinking in the students of the magistracy (formation of motivational readiness to perform professional functions; development of awareness of the social significance of professional activity; the formation and development of moral values, moral ideals, the notion of readiness for constant personal and professional growth, the basis of activity "human creation" and "man-centeredness").

Conclusion. Formation of the scientific elite in the students of the magistracy in the establishment of higher education requires the development of specific theoretical and practical principles of organization of educational process, in particular - trainings, the main purpose of which is the formation of the foundations of elitist thinking, skills and experience of behavior, as well as communicative activity with different categories of people; it is expedient to create initial selective courses that would provide the theoretical component of the preparation of graduate students precisely in the context of the scientific elite foundations formation.

Keywords: scientific elite; acmeology; institution of higher education; undergraduate students.

Одержано редакиією 05.01.2019 Прийнято до публікаиї̈ 12.01.2019

DOI 10.31651/2524-2660-2019-1-25-32

ORCID 0000-0002-2232-9072

\section{МОСКОВЧУК Наталя Миколаївна,}

аспірантка кафедри теорії та методики дошкільної освіти,

ПНПУ ім. К. Д. Ушинського,

УДК 372.2: 376 - $054.62+811.161 .2$

e-mail: moskovchuknata85@gmail.com

\section{РОЗВИВААЬНЕ УКРАЇНОМОВНЕ СЕРЕДОВИЩЕ ЯК ПЕДАГОГІЧНА УМОВА ФОРМУВАННЯ УКРАЇНОМОВНОЇ ПРОФЕСІЙНО-КОМУНІКАТИВНОЇ КОМПЕТЕНЦІї МАЙБУТНІХ ІНОЗЕМНИХ ФАХІВЦІВ ТЕХНІЧНИХ СПЕЦІААЬНОСТЕЙ}

У статті проаналізовано френомен "розвивальне комунікативно-украӥномовне середови ше для студентів-іноземиів технічного профілю" та уточнено його основні компоненти, а саме: "середовище" $i$ "розвивальне середовище". Наведено тлумачення науковиями поняття "розвивальне середовище" з погляду культурологічного, компетентнісного, екологопсихологічного, антропологічного, соиіальногенетичного, комунікативно-зорієнтованого й еколого-сочіального підходів. Запропоновано власне визначення поняття "розвивальне середовище". Визначено феномен "розвивальне комунікативно-украӥномовне середовище для студентів-іноземиів технічного профілю" та основні приниипи його конструювання.

ключові слова: середовише; розвивальне середовище; студенти-іноземиі технічного профрілю.

Постановка пробиеми. Система взаємовідносин суб'єктів закладу вищої освіти формує середовище, однією 3 не- обхідних характеристик якого в процесі україномовної підготовки іноземців $\epsilon$ розвивальна комунікація українською мовою, що сприяє розвитку особистісних якостей майбутнього фахівця із урахуванням його етнічної приналежності. Відповідно, однією з педагогічних умов формування україномовної професійнокомунікативної компетенції майбутніх іноземних фахівців технічних спеціальностей ми вважаємо наявність розвивамьного комунікативно-україномовного середовища дия студентів-іноземців технічного профілю.

Мета статті. Проаналізувати феномен "розвивальне комунікативноукраїномовне середовище дмя студентівіноземців технічного профілю" та уточнити його основні компоненти, а саме: "середовище" i "розвивальне середови- 
ще»; досиідити тиумачення поняття "розвивальне середовище" 3 погляду різних наукових підходів; запропонувати вцасне визначення поняття "розвивальне середовище" й феномена "розвивамьне комунікативно-україномовне середовище дмя студентів-іноземців технічного профілю" та основні принципи його конструювання.

Виклад основного матеріалу досмідження. Аналіз феномена "розвивальне комунікативно-україномовне середовище для студентів-іноземців технічного профілю" потребує уточнення його основних компонентів, а саме: "середовище" $\mathrm{i}$ "розвивацьне середовище».

Вивчення окремих аспектів поняття "середовище" відбувалося ще в 20-х рр. XX ст. В аспекті проблематики педагогіки середовища працювали К. Ушинський, М. Пирогов, О. Пінкевич, О. Аазурський, О. Аесгафт та ін. Уже на початковому етапі дослідження феномена "середовище" науковці вбачали його суть у двобічній взаємодії з особистістю:

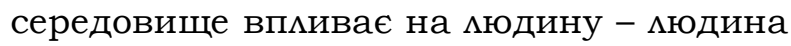
впливає на середовище. У цьому й полягає специфіка аналізу середовища: неможливо розглядати середовище відокремлено від особистості.

У довідковій мітературі поняття "середовище» визначається як сукупність природних або соціальних умов, за яких

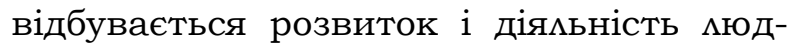
ського суспільства; соціально-побутові умови, в яких живе мюдина, довколишні умови; сукупність мюдей, пов'язаних спі$\Lambda$ ьністю умов [1].

Психомогічний характер взаємодії мюдини і середовища активно досліджується науковцями. Психологи $\Lambda$. Виготський і Д. ЕАьконін встановими залежність динаміки розвитку особистості від характеру іiі взаємодії із середовищем та змін, які в них відбуваються [2, с. 234-236]. С. Рубінштейн висловив засадничі ідеї щодо розвитку особистості у взаємодії із середовищем: "Аюдина не тільки об'єкт різних впливів, а й суб'єкт, який, змінюючи зовнішню природу, змінює і свою власну особистість, свідомо регулюючи свою поведінку. I розвиток Һюдини є нічим іншим, як становценням особистості - активного і свідомого суб'єкта продуктом взаємодії різних зовнішніх чинників, а "саморухом" суб'єкта, що $\epsilon$ вкАюченим у різноманітні взаємовідносини з довкімлям" [3, с. 184].
На думку Ю. Мануйлова, середовище - це те, посеред чого перебуває суб'єкт, за допомогою чого формується його спосіб життя, що опосередковує його розвиток [4, с. 5-7]. За М. Чорноушек, основними ознаками середовища $є$ відсутність фіксованих рамок у часі і просторі; од-

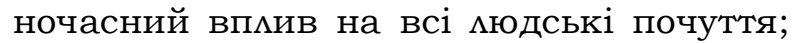
надання середовищем головної і вторинної інформації; наявність у середовищі більшої кількості інформації, ніж здатна осягнути мюдина; сприйняття його у зв'язку з діяльністю; існування мюдини одночасно у кількох середовищах [5, с. 25].

Істотний внесок у дос $і$ дження функцій і структури середовища в педагогіці зробила А. Богуш. Науковець визначає середовище як сукупність умов, які оточують мюдину та взаємодіють з нею як 3 організмом i особистістю. За низкою ознак учена розрізняє такі типи середовищ: найближче (родина, сім'я, родичі, друзі), далеке (суспільний устрій), зовнішнє, внутрішнє, пасивне, активне, актуальне i розвивальне; предметнопросторове, соціокультурне, мовменнєве (причому, кожне з них може бути розвивальним). У дослідженні А. Богуш розкрито особливості стихійного середовища, як такого, в якому відбувається пасивна взаємодія предметним і соціальним довкіляям, та стимульованого середовища, якому характерна максимамьно активна ініціативна взаємодія особистості з довкіллям та іншими учасниками соціуму. Таким чином, стимумьоване середовище забезпечує занурення педагогом учня до активної пізнавальної й комунікативної діяльності в навчальному закладі [6, с. 12, 76].

Серед визначених авторкою типів середовища особливу увагу привертає розвивальне середовище. На переконання А. Богуш, воно створює потенційні можливості дмя позитивного впливу різноманітних чинників в їхній взаємодії на інтелектуальний розвиток мюдини й формування цілісної особистості [6, с. 13]. Принципами побудови й організації такого розвивального предметного середовища є: дотримання дистанції та позиції у взаємодії, активність, самостійність, креативність і творчість; стабільність і динамічність, комплексування й зонування; принцип "емоційності середовища", індивідуальної комфортності й емоційного благополуччя кожного учня i вчителя; принцип відкритості й закрито- 
сті; врахування статевих і вікових відмінностей [6, с. 77 - 78].

Заслуговує на увагу дослідження А. Богуш культурологічного підходу до організації розвивального середовища в закладі вищої освіти в аспекті спадщини В. Сухомлинського. На основі аналізу педагогічних творів В. Сухомлинського вчена виокремила види соціокультурного середовища, які у взаємодії впливають на формування особистості майбутнього фахівця, зокрема: культурно-пізнавальне (впливає на інтелектуально-творчий i фізичний розвиток особистості, засвоєння нею культурно-сенсорних еталонів, а саме: культури відчуттів, сприймань, мислення, почуттів, волі, тобто психологічної і фрізичної культури), художньоестетичне (формує змістовий аспект художньо-естетичного й моральнодуховного розвитку майбутніх фахівців), культурно-комунікативне (сприяє вихо-

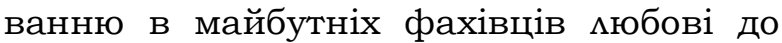
української мови, куцьтури мовлення й мислення), культурно-екологічне (сприяє формуванню моральних принципів через пізнання природи України та пізнанню національних особливостей українців), культурно-трудове (стимулює творчі здатності майбутніх фахівців), культурнорефлексивне (сприяє пізнанню й усвідомленню себе та внутрішній світ інших, органічний зв'язок свого "Я" із зовнішнім предметним світом, природою, довкілмям, іншими Аюдьми) $[7$, с. 8-11] .

А. Богуш зауважує, що здійснення культурологічного підходу до формування особистості в розвивальному середовищі закладу вищої освіти вимагає визначення відповідних принципів його реалізації, серед яких: принцип стимуювання у студентів потреби культурноціннісного пізнання й перетворення світу шляхом організації різноманітних сфер діяльності; принцип діалогічності, що полягає в реалізації різнорівневих і різнохарактерних діалогів (діалог мистецтв, діалог культур, природи, діалог довкілмя, діалог студентів і педагогів, внутрішній діалог свого "Я" із зовнішнім світоглядом); принцип дієво-творчої спрямованості навчально-виховної роботи зі студентами, що передбачає чітко визначену "культурнодоцільну" мету занурення ї в активно-творчу професійну діяльність; принцип свободи, самостійності й відповідальності, який дозволяє студентам самостійно визначати їнє ставлення до професії, навчання, природи, довкімля, мистецтва, комег, батьків тощо і відповідно оцінювати свою діяльність [7, с. 11]. Визначені авторкою принципи якнайкраще розкривають розвивальний потенціал мовменнєвого середовища не ізольовано, а у взаємодії з іншими соціокультурними сферами. Особливо результативною $є$ україномовна підготовка майбутніх іноземних фахівців у процесі їхньої соціалізації, активного входження в україномовне культурне, духовне, навчаАьно-наукове середовище.

Поняття "розвивальне середовище» в аспекті компетентнісного підходу досліджене Дж. Равеном, який тмумачить його як простір розвитку компетентності, у якому особистість має можливість прагнути до досягнення вцасних цікей і в процесі їх досягнення розвивати свою компетентність. Дж. Равен вважає, що "середовище розвитку компетентності" [8]:

- створює атмосферу поваги до переконань та рішень учасників навчального процесу;

- заохочує до розвитку і практикування нових стилів поведінки у процесі виконання завдань із високим рівнем мотивації;

- змушує майбутніх фахівців дбати про установу, в якій вони навчаються;

- забезпечує рольовими моделями в реальних чи віртуальних професійних ситуаціях;

- заохочує до постановки високих, але досяжних цілей, а також до моніторингу досягнень визначених цілей;

- забезпечує підтримку студента, якщо він не в змозі досягти очікуваних результатів;

- надає можливість уникати наявних помилок у майбутньому;

- забезпечує новими концепціями та відповідними альтернативами;

- забезпечує майбутнім фахівцям підтримку й допомогу, якщо вони припускаються помимок;

- забезпечує майбутнім фахівцям можливість ознайомлення з результатами іхньої діяльності, обговорення і визнання цих результатів.

В. Ясвін вважає розвивальним освітнє середовище, яке забезпечує комплекс можливостей для саморозвитку суб'єктів навчального процесу [9, с. 221]. Аналіз розвивального середовища здійснено науковцем 3 позиції екологопсихологічного підходу на основі чотирьохкомпонентної моделі середовища, 
яка складається 3: суб'єктів освітнього процесу, просторово-предметного компоненту (організація відповідного комплексу "розвивальних" стимулів); соціаАьного компоненту (міжособистісна взаємодія суб’єктів навчальної діяльності); технологічного компоненту (організація розвивальної діяльності суб'єктів освітнього процесу) [9, с. 172-234]. Найбі^ьшим потенціалом, на думку дослідника, характеризується розвивальне середовище, в якому не кише використовуються пропоновані середовищем можливості особистісного розвитку, але й самі учні організовують дия себе нові розвивальні можливості, що демонструє їхню свободу, активність і творчість [9, с. 116].

Актуальним $\epsilon$ аналіз розвивального середовища 3 погляду соціальногенетичного й комунікативнозорієнтованого підходів В. Рубцова. Досцідник спирається на слова С. Рубінштейна, який стверджував, що розвиток особистості в різних його проявах "залежить від змісту, який дитина опановує впродовж навчання, і від форми спілкування, зокрема, педагогічного впливу, в умовах якого цей вплив відбувається" [3, с. 176]. Відповідно до цього підходу, розвивальним, на думку В. Рубцова, можна вважати середовище, в якому розвиток особистості відбувається в процесі опановування нею багатовимірного й різнобічного інструментарію, вцастивого різним формам свідомості й діяльності. Автор пропонує проектувати конкретні освітні технології відповідно до трьох основних компонентів освітнього середовища: просторово-предметного (архітектурні особливості будівель, обладнання, особлива атрибутика); соціального (особлива, притаманна цьому типу культури, єдність суб'єктів навчання); психодидактичного (відповідний зміст освітнього процесу, діяльність, що засвоюється особистістю) [10, с. 27-28].

Антропопсихоцогічний підхід до анамізу розвивального середовища ми знаходимо в дослідженні В. Слободчикова, який вважає, що основною рисою розвивального середовища $є$ сумісне проектування іiі суб'єктами навчального процесу. Середовище з певними структурованими зв'язками й відношеннями, спроектоване учнем і вчителем, стає як предметом, так і ресурсом навчальної діяльності [11, с. 175].

О. Орлов конкретизує характеристики розвивального середовища під час навчання іноземної мови майбутніх фахівців технічних спеціальностей з позицій еколого-соціального підходу. На думку дослідника, розвивальний характер середовища забезпечується особистісно зорієнтованою спрямованістю навчання, педагогічною взаємодією суб'єктів освітнього процесу, суб'єктною діяльністю 3 вивчення дисципліни, сукупністю розвивальних структурних елементів середовища, специфікою досліджуваної дисципліни $[12$, с. 7$]$.

Отже, аналіз різних наукових підходів дав змогу дійти висновку, що "розвивальне середовище" - це сукупність просторово-предметних, соціокультурних i психодидактичних умов активної життедіяльності особистості, у процесі якої відбувається засвоєння нею соціального досвіду й засновничих моральних та куиьтурних цінностей 3 поступовою їхньою трансформацією у внутрішньоособистісні цінності, формування особистісних якостей та професійних компетенцій, самостійна і творча діяльність особистості.

Узагальнення різноманітних підходів до визначення поняття "розвивальне середовище" та аналіз його основних характеристик у контексті україномовної підготовки майбутніх іноземних фахівців дозволили визначити розвивальне комунікативно-україномовне середовище дмя студентів-іноземців технічного профілю як багатогранне, динамічне та поліфункціональне утворення, що забезпечує реацізацію сучасних педагогічних технологій i дозований вплив просторовопредметних, соціокультурних і психодидактичних умов (зокрема, мовценнєвої, навчально-мовменнєвої, художньомовценнєвої, театралізованої, комунікативної діяльності носіїв української мови), які надають можливість дмя активної україномовної мовленнєвої діяльності майбутнього іноземного фахівця одночасно із засвоєння ним моральних і культурних цінностей українського народу, формуванням особистісних якостей та здобуттям технічного фаху.

Оптимальним вплив розвивального комунікативно-україномовного середовища на мовмення майбутніх іноземних фахівців буде за наявності реалізації його розвивального потенціалу. Реалізація розвивального потенціалу комунікативно-україномовного середовища для студентів-іноземців технічного профілю вимагає ( за Дж. Равеном) [8]: 
- зміни концепції "викладаннявказування" на концепцію "викладанняпідтримка розвитку";

- концентрації уваги не на обсязі інформації, яку необхідно передати студентам, а на компетентностях майбутніх фахівців, які необхідно сформувати (відхід від статичного предметнознаннєвого змістового наповнення методик навчання з орієнтацією на розвиток репродуктивних мовленнєвих умінь, зорієнтованих на "середнього студента", що зумовлює низький рівень ефективності професійно-мовленнєвої підготовки майбутніх іноземних фахівців технічних спеціальностей);

- знання викладачами, окрім змісту дисципліни, особливостей психології розвитку особистості, дидактики, освітніх технологій;

- набуття майбутніми фахівцями індивідуалізованого, компетентніснозорієнтованого досвіду 3 метою формування у них відповідних компетентностей;

- суворого моніторингу викладачами реакцій студентів на отриманий досвід, застосування в разі необхідності корегувальних заходів.

Технічний заклад вищої освіти - це унікальне освітнє середовище, специфіка якого виявляється в полікультурності, домінуванні базових цінностей технічної культури, що передбачає розвиток у майбутніх фахівців переважно теоретичного (технічного) й абстрактного мислення, відносну самостійність та активність студентів у формуванні професійної компетентності. Сучасні дидактичні тенденції та орієнтація на технічний фах потребують активного впровадження в навчальний процес комп'ютерних техномогій. П. Сердюков вважає, що середовище, створене на основі комплексного застосування технічних засобів у навчаАьному процесі, є особливим соціотехнічним комунікативним навчальним середовищем, яке забезпечує засвоєння відповідних знань, умінь, навичок і формування іншомовної комунікативної компетенції шляхом підвищення ефективності сприйняття й опрацювання інформації, забезпечення сприятливих умов дия групової та індивідуальної навчальної діяльності з розвитку відповідних навичок і вмінь на основі комплексного сприйняття й опрацювання інформації водночас органами зору та слуху тих, хто навчається [13, с. 25]. Комп'ютеризація розвивального україномовного середовища забезпечує студентам можливість виявцяти самостійність у розв'язанні навчальних завдань, реалізувати теорію на практиці, поєднувати набуття знань із фаху 3 удосконаленням україномовної підготовки, встановцювати тісні міжособистісні контакти 3 іншими учасниками навчального процесу, створити віртуальне професійно зорієнтоване середовище тощо. Технологізація комунікативно-

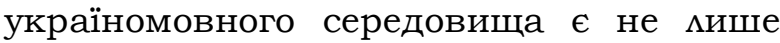
черговим дидактичним заходом, що забезпечує широке застосування активних методів навчання на заняттях 3 української мови, а й стає певною проекцію на майбутній фах через призму української мови.

О. Суригін стверджує, що педагогічна система навчання нерідною мовою характеризується двома особливими змінними: (1) зовнішне середовище, в якому відбувається життєдіяльність і навчально-пізнавальна діяльність учнів, і (2) мова як засіб взаємодії із середовищем та засіб навчально-пізнавальної діяцьності. У звичайних умовах навчання на батьківщині рідною мовою студент адаптований до рідного середовища й порівняно цегко долає пробцеми взаємодії із середовищем. Зовсім інша ситуація виникає під час занурення студента в нерідне середовище: найпростіша взаємодія обертається проблемами, вимагає значних зусиль для їх подолання. Автор нагомошує на неможливості не враховувати вплив зовнішнього середовища в моделі полімовної педагогічної системи, оскільки з практики навчання іноземних студентів добре відомо, що взаємодія ученьсередовище відчутно впливає на успішність інших взаємодій студентів. Зокрема, проблема взаємодії із середовищем може призводити до нездатності студента здійснювати навчально-пізнавальну діяльність і в крайньому їі прояві до необхідності повернення на батьківщину. Друга змінна - мова навчання, за допомогою якої здійснюється взаємодія із зовнішнім середовищем. Навчання іноземних студентів відбувається нерідною для них мовою, що вносить у процес функціонування педагогічної системи особАивості, якими також не можна нехтувати $[14$, с. 27$]$. 
3 огляду на висловлене вище, необхідно створити умови, за яких іноземець не просто має можливість, а змушений застосовувати мовленнєві знання й уміння продукувати україномовне висловлювання. Таким чином, нівелюється конфлікт між необхідністю висловлювання та його здійсненням, поліпшується психологічний стан мовця, активуються його розумові ресурси. Така необхідність виникне за умови занурення в розвивацьне комунікативно-україномовне середовище, в якому іноземний студент буде налаштований на спілкування українською мовою, оскільки українська мова стане єдиним можкивим засобом комунікації. Необхідно також враховувати, що у процесі україномовної підготовки у великих містах Східної і Південної України майбутні іноземні фахівці взаємодіють 3 російськомовним середовищем, в якому вони весь час перебувають, адже, на думку С. Свєтлєйшої, найважче засвоюється навчальний матеріал у діалектних умовах [15, с. 47].

Вирішенням проблеми навчання української мови дітей національних спіАьнот дошкільного віку, які проживають на території України, А. Богуш вважає дотримання принципу “одна особа - одна мова", що реалізується в закріпленні за кожною особою із середовища дитини однієї мови (української, російської, ангмійської тощо), якою вона бездоганно володіє у спілкуванні з дитиною. Оскіцьки на перших етапах навчання іноземцям складно, а подекуди неможливо, розрізнити мовмення мітературною українською мовою серед російського мовцення, діалектів та суржику, які особливо поширені на Східних та Південних регіонах України, вважаємо доречним дотримання принципу "одна особа - одна мова", що виявляється у визначенні максимальної кількості осіб, заходів, установ тощо, які стануть для іноземців орієнтиром і взірцем володіння українською $\Lambda$ тературною мовою [16, с. 13-14]. Вважмивим $€$ також визнання індивідуальності, цінності та самоцінності майбутнього іноземного фахівця як активного носія суб'єктивного досвіду, що сформувався ще на його батьківщині. Якщо виявлення та аналіз попереднього суспільноісторичного досвіду кожного студента спрямовані на взаємодію його з україн- ськими реаліями не шляхом "витіснення" суб'єктного досвіду, а шияхом узгодження та використання досвіду в процесі професійно-мовленнєвої підготовки, це сприяє ефективнішому конструюванню розвивального комунікативноукраїномовного середовища.

Аналіз різноманітних підходів до визначення понять "середовище" та "розвивальне середовище", узагальнення основних характеристик "розвивального середовища" в контексті україномовної підготовки майбутніх іноземних фахівців дозволили визначити чинники активізації розвивального потенціалу україномовного середовища для студентівіноземців технічного профілю та реалізувати ї у процесі україномовної підготовки майбутніх іноземних фахівців технічних спеціальностей. 3 позиції організації означеного середовища була організована робота з іноземними студентами, яка відбувалася у двох напрямах, які передбачають залучення студентів до: а) активної освітньо-дослідницької діяльності засобом виконання відповідних вправ та розробки проектів; б) безпосередньої участі в роботі науковотехнічних, науково-практичних та студентських конференцій.

Спочатку опишемо систему кожного напряму. У межах першого напряму майбутні іноземні фахівці виконували такі вправи: "Робота з фаховим текстом", "Ромашка Блума"; виконували індивідуацьні й групові проекти з тем "Я пишаюсь своєю батьківщиною", "Освіта в мережі", "Як заробити мільйон?", "Україна очима іноземного студента", "У здоровому тілі здоровий дух", "Праця - гроші", "На шляху до мети", "Час - найбільший скарб", "Мистецтво без кордонів", "Мораль і щастя", "Життя має смак", "Міф чи факт?", "Може один - можуть усі!";

У межах другого напряму студенти залучались до здійснення науководослідницької діяльності, студентських науково-практичних конференцій тощо. Зокрема, іноземні студенти взяли участь у науково-технічній конференції професорсько-викладацького складу, науковців, аспірантів та студентів ОНАЗ ім. О.С. Попова, де вони брали участь в обговоренні програмних питань. Перед конференцією іноземні студенти ознайомилися 3 iï програмою та підготували запитання до визначених проблем. Та- 
кож студенти брали участь у Міжнародній науково-методичній конференції " $\Lambda$ iнгвістична підготовка студентів нефікомогічних спеціальностей закладів вищої освіти в контексті Болонського процесу та Загальноєвропейських Рекомендацій з вивчення, викладання та оцінювання мов", що відбулась у м. Одеса в Одеській національній академії зв'язку ім. О.С. Попова. Студенти залучалися до діалогу між вітчизняними та іноземними науковцями. Особливо активно обговорювалася проблема використання технічних засобів в освітньому процесі: студенти висловили цікаві ідеї щодо впровадження педагогічних методів із використанням мережі Інтернет.

Досвід участі іноземних студентів у наукових конференціях дав можливість організувати студентську конференцію "Рух у майбутнє", де студенти презентували власні ідеї, досягнення, розробки, результати наукового пошуку тощо, пов'язані зі спеціальністю. Більшість студентів обирала тему відповідно до теми вцасної дипцомної роботи. Доповіді студентів було розподімено за секціями: "Рaдіозв'язок та телебачення" (секція 1); "Темекомунікаційні системи та мережі" (секція 2); "Інфокомунікації та програмна інженерія" (секція 3); "Інформаційна безпека" (секція 4); "Автоматизація та комп'ютерно-інтегровані технології" (секція 5; "Будівництво та архітектура" (секція 6). Тези доповідей, які були оформлені відповідно до стандартних вимог наукових видань, додавались у професійне мовне портфоліо майбутніх іноземних фахівців технічних спеціальностей. Основна увага у процесі організації та проведення студентської конференції була зосереджена на усних доповідях іноземних студентів. Кожен доповідач відповідав на запитання, які ставили викладачі фахових дисциплін, викладачі української мови як іноземної та студенти. Керівник конференції підтримував доброзичмиву й невимушену атмосферу, що дало змогу підвищити активність студентів в обговоренні проблемних питань.Участь у конференції сприяла формуванню умінь україномовного пубцічного виступу на наукову тематику та була своєрідним тренуванням перед захистом дипломних робіт студентів.
Висновки. Дослідження понять "середовище" й "розвивальне середовище", відстеження особливостей організації та діагностика результатів реалізації розвивального комунікативно-україномовного середовища дия студентів-іноземців технічного профілю дозволяє визначити його як ефективну педагогічну умову україномовної підготовки майбутніх іноземних фахівців технічних спеціальностей.

\section{Cписок бібліографічних посимань}

1. Толковый словарь русского языка : В 4 т. / под ред. Д. Н. Ушакова. М.: Гос. Ин-т "Сов.энцикл."; ОГИЗ ; Гос. Изд-во иностр. и нац. слов., 1935. $940 \mathrm{c.}$

2. Виготский $\Lambda$. С. Собрание сочинений в 6 томах. Т. 4. Детская психомогия. / под. ред. Д. Б. Эмьконина. М.: Просвещение 1984. C. $234-236$.

3. Рубинштейн С. $\Lambda$. Основы общей психологии: в 2 т. Т.1. М.: Педагогика, 1989. 488 с.

4. Мануйлов Ю. Концептуальные основы средового подхода в воспитании. Вестник Костромского государственного университета им. Н. А. Некрасова. 2008. Т. 14. Серия: «Педагогика. Психология. Социальная работа. Ювенология. Социокенетика". № 1 . С $5-7$.

5. Черноушек М. А.Психология жизненной среды. M., 1989. 174 c.

6. Богуш А. М., Гавриш Н. В. Методика ознайоммення дітей з довкіллям у дошкільному навчальному закладі : підручник. К.: Слово, 2008. 408 с.

7. Богуш А. Кумьтуромогічний підхід до організації розвивального середовища у вищому навчальному закладі в аспекті спадщини В. Сухомиинського. Наука і освіта. 2010. № 7. С. 8-11.

8. Raven J. Facilitating the Development of Competence. URL: http:// www.eyeonsociety.co.uk /resources/CILSChap18.pdf.

9. Ясвин В. А. Образовательная среда: от моделирования к проектированию. М.: Смысл, 2001. $365 \mathrm{c}$.

10. Рубцов В. В., Ивошина Т. Г. Проектирование развивающей образовательной среды школы. М.: Изд-во МГППУ. 2002. 272 с.

11. Слободчиков В. И. О понятии образовательной среды в концепции развивающего образования. М.: Экопсицентр РОСС, 2000. 230 с.

12. Орлов А. В. Формирование развивающей образовательной среды в процессе обучения студентов иностранному языку в техническом вузе: автореферат диссертации на соискание ученой степени кандидата педагогических наук: 13.00.08 / Алтайский государственный технический университет им. И. И. Ползунова. Барнаул 2013. 22 c.

13. Сердюков П. I. Теоретичні основи навчання іноземних мов у мовному вузі з використанням інформаційних технологій: автореф. дис. ... на здобуття наук.ступеня д-ра. пед. наук: 13.00.02 / Київ. держ. мінгв. ун-т. К., 1997. 32 с.

14. Сурыгин А. И. Педагогическое проектирование системы предвузовской подготовки иностранных студентов. СПб.: ЗАатоуст, 2001. 128 с.

15. Свєт єйша С. М. До питання про вивчення мексики російської мови учнями українських шкіл в діалектних умовах. Шляхи посилення практичноі спрямованості у викладанні близъкоспоріднених (українсъкої $i$ російсъкої) мов: тез. доп. наук.метод. конф. Одеса, 1990. С. $46-47$. 
16. Богуш А. М. Навчання дітей української мови в дошкільних навчальних закладах національних спільнот: програма та навчально-методичний посібник. Тернопімь: Мандрівець, 2016. 136 с.

\section{References}

1. Explanatory Russian Dictionary: In 4 t. (1935). D. N. Ushakov (Ed.). M.: State. Un-t "Soviet Encyclopedia"; USP; State Publishing House of Foreign and National words (in Russ.).

2. Vihotsky, L. S. (1984). In D. B. Elkonin. Children's Psychology. Collected Works in 6 Volumes. V. 4. M.: Education. (in Russ.).

3. Rubenstein S. L. (1989). Fundamentals of General Psychology: in 2 Volumes. Vol.1. M.: Pedagogics (in Russ.).

4. Manuylov, Yu. (2008). Conceptual Bases of Environmental Approach in Education. Bulletin of $\mathrm{Ko}-$ stroma State University n.a. N.A. Nekrasov.. Vol. 14., Series: "Pedagogics. Psychology. Social work. Youth studies. Socio-kinetics", 1. 5-7. (in Russ.).

5. Chernoushek, M. A. (1989). Psychology of Vital Environment. Moscow (in Russ.).

6. Bogush, A. M., Gavrysh, N. V. (2008). Techniques for Familiarizing Children with the Environment in Preschool Educational Institution: Textbook. Kyev: Word (in Ukr.).

7. Bogush, A. (2010). Culturological Approach to Creating Developing Environment in a Higher Educational Institution in the Context of V. Sukhomlynsky's Heritage. Science and Education, 7, 8-11 (in Ukr.).

8. Raven, J. Facilitating the Development of Competence. URL: http://www.eyeonsociety.co.uk /resources/CILSChap18.pdf
9. Yasvin, V. A. (2001). Educational environment: from Modeling to Design. M.: Sense (in Russ.).

10. Rubtsov, V. V., Ivoshyna, T. G. (2002). Design of the Developing Educational Environment of School. M.: MSPPU Publishing House (in Russ.).

11. Slobodchikov, V. I. (2000). About a concept of the educational environment in the concept of the developing education. M.: Ekopsicentre ROSS (in Russ.).

12. Orlov, A. V. (2013). Creating Developing Educational Environment in the Process of Foreign Language Training of Students at Technical Universities (PhD dissertation). Theses. Altai State Technical University n.a. I. I. Polzunov. Barnaul (in Russ.).

13. Serdyukov, P. I. (1997). Theoretical Bases of Foreign Languages Studies in Language Higher Education Institution Using Information Technologies (Doctor of Science dissertation). Theses: Kyiv. State Ling. Un-t (in Ukr.).

14. Surygin, A. I. (2001). Pedagogical Design of a System of Prehigh School Training of Foreign Students. St.P.: Zlatoust (in Russ.).

15. Svietlieisha, S. M. (1990). To the Question of Russian Lexicon Acquisition by Pupils from Ukrainian Schools in Dialect Conditions. Ways of Strengthening Practical Orientation in Teaching Closely Related (Ukrainian and Russian) Languages: Thesis of Scien. and Method. Conference. Odesa (in Ukr.).

16. Bogush, A. M. (2016). Teaching Children of Ukrainian in Preschool Educational Institutions of National Communities: a Program and Educational and Methodical Textbook. Ternopil: Mandrivets (in Ukr.).

\section{MOSKOVCHUK Natalya,}

Postgraduate student at the Faculty of Theory and Methods of Preschool Education,

State institution "South Ukrainian National Pedagogical University named after K. D. Ushynsky",

\section{DEVELOPING UKRAINIAN ENVIRONMENT AS A PEDAGOGICAL CONDITION FOR FOSTERING UKRAINIAN LANGUAGE PROFESSIONAL AND COMMUNICATIVE COMPETENCE AMONG FOREIGN SPECIALISTS-TRAINEES FROM TECHNICAL SPECIALTIES}

Introduction. The system of relationship between subjects from institutions of higher education forms the environment where providing Ukrainian communication is one of the required characteristics in the course of Ukrainian training of foreigners. It promotes enhancing personal qualities of a specialist-trainee taking into account his ethnic origin. Respectively, developing communicative and Ukrainian environment for foreign students of a technical profile is considered as one of the pedagogical conditions for fostering Ukrainian language professional and communicative competence among foreign specialists-trainees.

Purpose. To analyze a phenomenon of "developing communicative and Ukrainian environment for foreign students of a technical profile" and to specify its main constituents.

Results. The analysis of different scientific approaches allowed arriving at the conclusion that "developing environment" is a set of spatial and subjective, sociocultural and psychodidactic conditions of an individual's activity. On the one hand, in this process one may observe assimilation of students' social experience, on the other hand, here occurs transformation of their fundamental moral and cultural values and gradual interfusion with their internal values. This process is also conducive to advancing learners' personal qualities and professional competences, as well as creative activity.

Summarizing various approaches to the concept of "developing environment" and analyzing its main characteristics in the context of Ukrainian language teaching foreign specialists-trainees allowed defining the develop- ing communicative and Ukrainian environment for foreign students of a technical profile as a complex, dynamic and polyfunctional process. For an improved training it requires implementing modern pedagogical technologies. It also provides proportioned influence of Ukrainian language speakers on foreign specialist-trainees in spatial and subjective, sociocultural and psychodidactic conditions, and ensures an opportunity to obtain a technical profession, familiarize with moral and cultural values of Ukrainians, and advance their own personal qualities.

Originality. The article identifies the factors of activating developing potential of the Ukrainian environment for foreign students of a technical profile and specifies the conditions of realizing these factors in the course of teaching foreign specialists-trainees from technical specialties.

Conclusion. The carried out research permitted to conduct a manyfaceted analysis of the concepts "environment" and "developing environment" targeted at identifying the techniques of diagnosing potentials of using developing communicative Ukrainian language environment for training foreign students of a technical profile. All given, it can be defined as an effective pedagogical condition for teaching foreign specialiststrainees.

Keywords: environment; developing environment; foreign students of a technical profile. 